\title{
Vegetable production based on waste heat in closed greenhouses considering economic usage and competitiveness of the European Union
}

\author{
Zoltán Eperjesi \\ Metropolitan Public Domain Maintenance Ltd., Buckinghamshire \\ zoltan.eperjesi76@gmail.com
}

SUMMARY

\begin{abstract}
The study investigates two professional fields; the questions of vegetable production in greenhouses, the necessary steam supply and heat regulations.

The actuality of this investigation is provided by the planning of a combined cycle power plant of $2400 \mathrm{MW}$ in Hungary. According to the plans the steam developing by generating electricity in the power plant can be used to intensify the vegetable production.

In my current study I present the experiences and results gathered as member of the research and development team led by Mr. Dr. SinórósSzabó.
\end{abstract}

Keywords: Hungarian energy sector, combined cycle power station on natural gas basis, waste heat utilisation system

\section{ÖSSZEOGLALÓ}

A tanulmány két szakmai területet vizsgál, az üvegházban történő zöldségtermesztés kérdéseit, valamint a szükséges gözellátást és höszabályozást.

A kutatás aktualitását legföképp a Magyarországra tervezett 2400 MW teljesitményü kombinált ciklusú erömü adja. A tervek szerint az elektromos áram elöállitása során keletkezö höt kiválóan lehet hasznositani a zöldségtermesztés hatékonyságának növelésében.

Jelen tanulmányomban részletesen szemléltetem az elvégzett kisérleteket és gyüjtött tapasztalatokat, amelyeket dr. Sinóros-Szabó Botond professzor úr fejlesztö csoportjának tagjaként szereztem.

Kulcsszavak: magyar energiaszektor, kombinált ciklusú földgázalapú erömü, hulladékhöhasznositó rendszer

\section{THE HUNGARIAN ENERGY MARKET}

The total capacity of the Hungarian power plants with high performance ( $>50 \mathrm{MW})$ made up $8000 \mathrm{MW}$ in 2005. No further power plant capacity of considerable size was built since then. The biggest change has been, that the power plant in Pécs, Ajka, and Kazincbarcika can be fuelled beneath the coal also by biomass. The biggest Hungarian power plant fuelled by natural gas and oil is called Dunamenti Power Plant. The second largest power plant is the Paks Atomic Power Plant producing $40 \%$ of the Hungarian electricity production. Most of the Hungarian power plants are located in former heavy industry areas and Budapest. There were two main criteria - the cooling water and the nearness of the oil pipeline - where to settle the power plants. The regions of the Great Plain do not dispose of considerable capacities. That is why big energy consuming industries cannot be found in the region.

\section{THE CURRENT STRUCTURE OF THE HUNGARIAN ENERGYSECTOR}

The consumption of the primary energy sources has stagnated over the last 20 years while the structure of the consumption and the economic structure parallel changed. Several units of the former energy consuming industrial companies were closed due to failing competitiveness so the energy consumption did not follow the increase of GDP. The annul energy consumption made up almost the same quantity in 1993 as in 2006 . Despite of the GDP increase on contrary of energy consumption, the ratio of GDP and energy consumption shows a quite unfavourable high value. This phenomenon can be explained that the Hungarian GDP is considerably less than the GDP of the developed Western European countries. The Western European countries' ratio makes up only one-third of the Hungarian value. This ratio is a reminder for Hungary to extend energy saving production methods. The energy needs of Slovakia are ten times higher than the needs of Denmark.

The Hungarian energy source structure looks like as follows: $43.9 \%$ natural gas, $32.5 \%$ liquid fuels, solid fuels and renewable energy sources $14.3 \%$, primary electricity generated by atomic power plants $13.9 \%$. The renewable energy sources have only a share of $3.6 \%$ within the total energy consumption. The share of renewable energy sources in Hungary lags behind the European average of 6\% (Communication of the European Commission to the European Parliament, to the European Council and to the Economic and Social Commission; Energy agenda lasting until 2050, 2011). Natural gas is decisive, dominant energy source in Hungary. The natural gas quantity used to produce energy made up 13 billion $\mathrm{m}^{3}$ in 2005 from which quantity $22 \%$ was made up by the domestic production. $78 \%$ of the domestic natural gas consumption is imported from Russia via Ukraine and Austria. The import sources of natural gas are not at all diversified that means the vulnerability of the security of the domestic demand. Even the gas dispute between Russia and Ukraine in 2006 did not cause difficulties in the domestic natural gas supply. Commercial and technical conditions need to be fulfilled so that the natural gas supply sources can be extended. New supply contracts should be concluded and new transit gas 
pipelines should be built. Expensive investments need to be accomplished to loosen the interdependency of natural gas supply. All these targets need international co-operation and the share of the burdens. Attention has to be paid to the extension of the domestic storage facilities beneath the continuous increasing natural gas demand. Natural gas demand makes up $44 \%$ of the total Hungarian energy consumption. Considerable part of the gas supply is used for heating purposes but electricity production becomes more and more important. The new Hungarian capacities of electricity production were based on natural gas after the political change over.

The Hungarian electricity demand made up 40599 GWh in $2005,18 \%$ of which was covered by import. The power plants for public use produced 32582 GWh, from which $36.6 \%$ fell upon atomic power station. $58 \%$ of the production of the heat power plants were based on carbo-hydrogen, $44.6 \%$ on coal basis, while the remainig $2.6 \%$ was based on biomass. The households has a share of $31.7 \%$ within the entire electricity consumption.

The biggest industrial electricity consumer is the manufacturing industry with its $36.1 \%$ proportion. The Hungarian electricity demand grows by $1.8-2 \%$ annually. This trend seems to continue in the future as well. The increase of the electricity consumption will generate new power plant capacities of 7700-7800 MW because some of the old power plants will cease to produce meanwhile.

The share of the fossil energy sources in the primary energy balance will somewhat increase from $82 \%$ up to $84 \%$ by 2030 . The coal and oil proportion will decrease by $4-5 \%$ but the share of natural gas will increase at the same time. The slight increase of the fossil energies, first of all the growing importance of the natural gas demand may project growing carbon-dioxide output, but it has to be mentioned that it will not reach the measured value of 1985 .

\section{EUROPE 2020 STRATEGY AND THE EUROPEAN ENERGY STRATEGY}

The Europe 2020 strategy is based on three decisive priorities:

- securing the continuous growth, whose essence is the knowledge and innovation based economy;

- sustainable development, that necessitates the raw material saving, competitive economy considering environment protection aspects;

- endogenous economy based on social development requiring high employment and social and territorial cohesion.

The European Commission established the targets

to be reached by 2020 . The 5 targets are as follows:

- employment of $75 \%$ of people aged between 20 and 64 years;

- $3 \%$ of the total GDP of the European Union should be spent on research and development;

- fulfilment of the ,20/20/20” climate energy goals;

- number of children leaving school before ending should be reduced under $10 \%$ and $40 \%$ of the young generation should dispose of diploma;
- the number of people living under the poorness level should be reduced by 20 million people by 2020 (Communication from the Commission, Europe 2020, 2010).

The Energy 2020 strategy and targets exactly formulate the policies and measurements to be executed so that the greenhouse gas emission may be reduced up to 80 $95 \%$ of the year 1990 . The Energy strategy further strives to decrease the energy consumption of the EU by $20 \%$ by 2020 . The renewable energy sources should reach $20 \%$ in the energy demand and $10 \%$ in the transportation sector of the EU. The European Commission investigates the challenges in the Energy Agenda lasting until 2050 how the target of coal-dioxid reduction can be achieved and the security of energy supply and competitiveness can be granted. The agenda was worked out upon request of the European Council.

In the next 10 years a new investment cycle should begin because the energy infrastructure built 30-40 years ago needs to be modernised. It is certain that electricity will have an increasing role in the future. Its share will almost double concerning final energy needs, exceeding 36-39\%. According to every carbondioxide reduction agenda, considerable energy saving has to reached. The demand for primary energy will decrease by $16-20 \%$ by 2030 and by $32-41 \%$ until 2050. All member states have to work out measures for their economic sectors and the decisive division between economic growth and energy consumption has to be met. The proportion of the renewable energy sources will considerably grow according to all energy agendas, reaching $55 \%$ of the total gross energy demand. This proportion would be $45 \%$ higher than the current value. Separation and storage of coal-dioxide that will be commercialised is a pioneer innovation. On the market of separation of coal dioxide the EU could acquire a pioneering role in the world market. Attention is to be made to risks caused by controversial effects of climate policies and competitiveness. The European competitiveness is shrinked when coal dioxide separation is performed only by the EU. According to estimations the price of electricity in the EU is by $21 \%$ higher than in the USA and by $197 \%$ higher than in China. The nuclear energy will play an important role in the conversion of the energy systems of countries where it is still used.

The decentralisation of the electricity production system and the heat production grows as a result of the increasing renewable energy generation. The different agendas show that the centralised systems of big size like the power plants fuelled by nuclear energy and natural gas and the decentralised systems have to co-operate. In the framework of the new energy system, a new structure of centralised and decentralised systems has to be established that can mutually aid each other, for example, if the local energy sources are not sufficient (table 1).

\section{COMBINED CYCLE POWER STATION ON NATURAL GAS BASIS}

In harmony with the development plans $2400 \mathrm{MW}$ capacity, natural gas combined cycle power station will be built to produce electricity in Hungary's eastern 
three-border segment, in the North- Great Plain region, in Szabolcs-Szatmár-Bereg county, in Baktalórántháza Small-region.

The foundation stone of the power station head offices was put down in Nyírtass in June 2008.

The University of Debrecen formed an efficient cooperation on the big scale strategic development of the region and on the realisation of the program.

A Hungarian professor team-using international cooperation and experiences-worked out the thermo energetical analysis and thermo energy utilizing strategy of the $2400 \mathrm{MW}$ capacity combined cycle heat power station, which will be built in Hungary's eastern threeborder segment.

Table 1.

Primary energysources utilization between 2000-2030 in the $\mathbf{E U}$

\begin{tabular}{lcccc}
\hline $\begin{array}{c}\text { Primary energy } \\
\text { sources }\end{array}$ & 2000 & 2010 & 2020 & 2030 \\
\hline Solid fuels & 30,1 & 37,4 & 50,8 & 65,7 \\
Liquid fuels & 76,5 & 81,4 & 86,1 & 88,5 \\
Natural gas & 49,5 & 61,4 & 75,3 & 81,4 \\
\hline Altogether & 47,2 & 53,3 & 62,1 & 67,5 \\
\hline
\end{tabular}

Source: Csom (2006)

WASTE UTILIZATION SYSTEM OF COMBINED CYCLE POWER STATIONS

The heat utilization system of a combined cycle power station (hereafter: power station) means the growth of agricultural products-mainly vegetablesunder controlled circumstances (,glasshouses").

The idiosyncrasy and also the speciality of the system is the heat utilizing unit producing mainly vegetables and ornamentals, but fish breeding, drying plants and heated garners could be organic units of heat utilization as well. The power station heat utilizing system provides four special advantages:

1. The thermal capacity of the combined cycle thermal power station increases significantly compared with the planned $54 \%$ by using the connected heat utilizing system.

2. The combined cycle thermal power station produces food by utilizing the waste heat and provides heat energy at the same time. This way the social-, economic-, environmental- and human environmental embededness will be especially high in the eastern neighbouring border areas.

3. The thermo-energy quantum leaving the power station as a result of waste heat utilization will be so low that it will not harm the environment in any way-for sure.

4. The heat utilizing unit produces the required thermoquantity and temperature for growing vegetablesornamentals and the $\mathrm{CO}_{2}$ fertilization (needed for intense growth) by flue gas (containing $\mathrm{CO}_{2}$ ) leaving the gas turbines. This way the flue gas does not increase the $\mathrm{CO}_{2}$ content of the air, on the contrary, it decreases the value of that compared with the ones of the power station. All these support the fulfilment of the required $\mathrm{CO}_{2}$ quota of the power station and they mean maximizable advantages.

\section{STRUCTURE OF THE HEAT UTILISING UNIT}

The thermoenergetical data of the combined cycle thermal power station were considered as bases according to the followings. For the calculations we considered the 800 MW capacity unit to be built in the first phase of the investment.

Raw data of waste heat supply - (waste heat of $800 \mathrm{MW}$ axle capacity gas turbine):

- waste heat: $\sim 1180 \mathrm{MW}$,

- mass flow of steam produced by waste heat:

$\sim 320 \mathrm{~kg} \mathrm{sec}^{-1}$ (dry saturated steam),

- steam pressure: 2,5 bar,

- steam temperature: $120-130{ }^{\circ} \mathrm{C}$.

The heat utilizing unit consists of the following system presumed and operating units:

Operating units:

- vegetable production,

- ornamental production,

- herb production,

- warm water fish breeding,

- drying plants.

Service units:

- thermo- and flue gas service,

- facilities- and material supply (garners, stores),

- technical-technological services (plant maintenance, material, components, etc.),

- transportation, material moving.

Product storing.

- controlled atmosphere stores.

The available facilities make it possible to use the most advanced technology (high-tech) and due to it to produce top quality products. This way it becomes possible to reach the richest, the most ambitious, the so called luxury consumers. This type of consumers can be found to the west and east of us. Several reasons support considering the latter one mainly (the relative closeness of markets, smaller transportation distance, earlier trading contacts). In the interest of this, the opportunities „hidden” in the eastern markets have to be discovered and utilized as soon as possible. Considering the changing weather, top quality products can only be made under regulated circumstances. This production concept suggests the availability of glass covered, high atmosphere (in which tomato secures a nearly one-year production cycle) equipment and the natural ability to produce without soil.

\section{CONCLUSIONS}

The heat utilizing project system of the power station is a significant strategic development either from a naturalsocial- and economic point of view. The advantages of all this appear not only in the profit producing efficiency of each project, but they also fulfil small regional, county, regional and governmental objectives, too. In the interest of project investments and their wider emergence, the harmony between project financing and regional 
development must be found. The market environment of the logistical step can be described by a 250-kilometer-diameter circle. All this means that the markets of the products made within the frames of the heat utilizing project penetrate into the neighbouring countries as well and effect the half of the Great Plain. In the effected area 5 million people live, who can provide a market for the products.

The projects operating in the field of heat utilization form an interdependent system. (Closed atmosphere manageable plastic houses-fish breeding-drying.) The traditional and special vegetable projects realise an especially high profit, but on the other hand, they require a lot of labour force. The raw data can be found in the study. To demonstrate the sizes, we summarized some typical data of closed atmosphere tomato growing.

1 ha tomato growing:

- manning requirement: 80-90 people,

- average yield: $750 \mathrm{t}$,

- investment: 180 million Ft,

- constant and variable costs: $50-60 \%$ of gross receipts. Thermo-energy utilizing projects have a lot of special advantages. One of the biggest tasks is to supply enough and of the appropriate quality labour force. This requires a sophisticated and harmonised logistics system and training programme. The different forms of training programmes are integrated and built on each other:

- individual course training (training, retraining, continuing trainig),

- skilled labourer training,

- higher training,

- university-college training, B.Sc., MSc.

In the plan defined 4000-6000-people constant labour force supply is systematically prepared and it is a challenging task. The supply of this number must partly be based on families (their motivation). The size of the necessary plastic house $(0.5-1.0 \mathrm{ha})$ must be determined for them. Apart from the families, the students of the University of Debrecen and the College of Nyíregyháza should be involved in the project, harmonising their practical training with their financial motivation. Overall it can be stated that the realisation of heat utilizing projects of the combined cycle power station creates such advantages for the project, the power station, the region and the eastern border region which justify the realisation of the heat utilizing project.

\section{REFERENCES}

Communication from the Commission, Europe 2020 (2010): A strategy for smart, sustainable and inclusive growth. Brussels. 4.

Communication of the European Commission to the European Parliament, to the European Council and to the Economic and Social Commission; Energy agenda lasting until 2050 (2011): COM (2011) 885 final. Brussels. 10.
"BIOENKRF" Bioenergy Consortium: Combined cycle power station waste heat utilisation in the region of Vásárosnamény, leading expert: Dr. Sinóros Szabó Botond, Doctor of the Hungarian Science Academy. 15 